\title{
Lecturers' Perceptions on Challenges and Expectations on Work Conditions: Case of Zimbabwe Rural State University
}

\author{
Munyaradzi Chidarikire $(\mathrm{PhD})$ \\ Bindura University of Science, Office Number G28 \\ Faculty of Science Education complex, Bindura, Zimbabwe \\ E-mail: mchdas78@gmail.com
}

Received: May 7, 2021 Accepted: June 9, 2021 Published: June 16, 2021

doi:10.5296/ijssr.v9i2.18761 URL: https://doi.org/10.5296/ijssr.v9i2.18761

\begin{abstract}
This qualitative paper explored the Zimbabwe rural university lecturers' experiences, challenges, and expectations in the execution of their duties, as they are highly de-motivated. The Zimbabwe Higher and Tertiary Education 5.0 thrust states the roles of universities as consisting of five critical issues: Teaching, Research, Community Engagement, Innovation, and Industrialization have been greatly affected by challenges cited in this article. There is a dearth of literature on the challenges faced by and there is a lack of solutions propagated by lecturers in universities located in rural areas in Zimbabwe. The quality of teaching and learning outcomes in Zimbabwe universities have been deteriorating due to financial, high workload among others. Hence, there is a need to engage in this study to find university lecturers' views on how these challenges should be addressed to enhance the quality of teaching and learning outcomes. Abraham Maslow's theoretical framework and narrative paradigm were used in this paper. A purposive sample was used to select nine knowledge-rich university lecturers from Faculty of Education. Data was generated through focus group discussions and content thematic analysis was used to analyze data. The participants responded to two critical questions: 'what are the challenges faced by rural university lecturers and what should be done to mitigate challenges affecting lecturers in rural areas?' This article found that highly qualified university lecturers in Zimbabwe are leaving rural universities to international universities seeking greener pastures. Therefore, the paper recommended that Zimbabwe university lecturers should receive salaries and other benefits at par with international universities.
\end{abstract}

Keywords: universities, lecturers, rural areas, challenges, hierarchy of needs 


\section{Introduction}

There are thirteen universities in Zimbabwe, of which nine state universities and four church-run universities. Most universities are located in urban areas and few universities are located in rural areas. Currently, many challenges are affecting lecturers in rurally located universities in Zimbabwe that have led the great exodus of qualified and experienced lecturers to greener pastures abroad (Ministry of Higher and Tertiary Education, 2009; Newsday, 2008). In America, some university lecturers experience problems associated with job security issues as they are employed on a one-year term subject to renewal (Petry, 2011). Short-term employment contracts given to some lecturers in American universities have created uncertainties due to job losses. According to O'Hara (2015), some Britain university lecturers are earning very low salaries as compared to their counterparts in other countries such as America. These universities' low salaries are affecting lecturers who are in lower grades and this has de-motivated and incapacitated them. Contrary, Universities' lecturers in America and Britain who are in higher grades of employment are earning better salaries and this has created conflict between those in lower and higher grades (Petry, 2011; O'Hara, 2015). Koen (2003) found that black female university lecturers are experienced poor working conditions as compared to male counterparts.

In Japan, other university lecturers experience stress due to high workloads and other personal challenges such as health issues (Haung, Daizen, \& Kim, 2017). On the other hand, Nigerian universities are experiencing poor funding from the Government and private sector this negatively affects lecturers' work concerning lack of financial support in areas such as research projects (Udefi, 2014). In addition, Salako (2014) found that Nigerian universities are facing deteriorated infrastructure such as buildings and road networks. Some South Africa university lecturers are facing challenges in using Moodle learning methods due to a lack of training (Mpungose, 2020). This shows that university lecturers are frustrated from using internet learning platforms but prefer to use face-to-face teaching rather than online teaching (Gumbo, 2019). In Zimbabwe, some studies have been done on challenges facing urban universities in Zimbabwe focusing on research and publication, quality assurance, and loss of qualified lecturers (Kariwo, 2007; Majoni, 2014; Nherera, 2000). Therefore, there is a need to engage in the study to explore the challenges and solutions to mitigate challenges faced by lecturers in universities located in rural areas.

\section{Theoretical Framing: Maslow Hierarchy of Needs / Motivation Theory}

This paper is located within Abraham Maslow's hierarchy of needs / motivation theory and 1 used its five levels namely: physiological needs, safety needs, love and belonging, self-esteem needs, and self-actualization to couch this study. In this article, I argued that university lecturers at universities located in rural areas have physiological needs such as habitable shelter, clean and available water, food, and clothes. According to Mwamwenda (2014) teachers and students need food, shelter, and clothes to survive and execute their duties with peace of mind and healthy bodies. Therefore, lack of water and medication negatively affects teaching and learning in rural areas (Chidarikire, Hlalele, \& Tarisayi, 2021). In addition, university lecturers working in the rural set - up have safety needs such as a work 
environment that is free from psychological, physical, emotional threats and dangers (Snowman et al., 2005). Motivation theory, argues that lecturers need to love and to be loved by other colleagues, students, communities, management, and other stakeholders (Santrock, 2009). Rural lecturers may be affected by poor self-esteem due to the rural location of their universities. To this end, Maslow's motivational theory argues that lecturers should be given extrinsic and intrinsic motivation such as promotion and awards to increase their self-worth and values (Mwamwenda, 2014). Lastly, lecturers need to reach self-actualisation level, where they reach the highest level of their personal and professional attainment. From the above assertion, 1 argued that this motivation theory by Maslow is suitable as its tenants are applicable in motivating lecturers towards achieving their goals academically, professionally, and personally.

\subsection{Methodology}

This qualitative paper focused on exploring the rural university lecturers' experiences, challenges, and solutions to mitigate challenges faced by lecturers working in rural universities. Qualitative research permits the use of multiple perspectives on the phenomena (Cohen et al., 2018; Thao \& Herman, 2020).

\subsection{Research Design}

According to Creswell and Poth (2018) research methodology reflect how the study is structured in an organized manner with the thrust of generating data as the responses to the critical questions posed by the researcher. I used exploratory survey design that utilized qualitative research methodology. Exploratory survey design helped in this study as it permitted the participants to explore and interpret their lived experiences in relation to work conditions (Chinyoka \& Ganga, 2014). The participants in this article gave their perspectives through actively participating in focus group discussions.

\subsection{Population and Sample}

Cohen et al, (2018) define population as total number of people that qualify to participate in the study. In this article, all 45 lecturers from Faculty of education from one university in Zimbabwe located in rural areas. However, as noted by Creswell (2010), it is impossible to use the entire population in the study; therefore, 1 used nine knowledge-rich participants were purposively selected from the Faculty of Education. These lecturers were from Educational Psychology (3), Sociology (3), and Philosophy (3). To effectively select the knowledge rich participants, 1 used purposive sampling technique. These participants were selected based on the following predetermined criterion namely: knowledge of the topic under study, gender and full-time lecturers

\subsection{Instrumentation}

I used one focus group discussions as an instrument to generate data from the participants (Creswell \& Poth, 2018). During focus group discussions, ground rules were agreed upon between participants and the researcher, such as punctuality. The participants responded to two critical research questions: "what are the challenges faced by rural university lecturers 
and what should be done to mitigate challenges affecting rural university lecturers?' Group discussions were held for three days, 1 hour each session (total of three hours). In line with Covid-19 regulations, participants observed social distance, sanitized and wore face masks (Sowetan, 2020). The participants' views from both focus groups were recorded by the research secretary and the data were put into coded put into themes through using the stages proposed by Braun and Clarke (2006): familiarization with data, data coding, searching for themes; review themes; defining and naming the themes data analysis and write up. The data generated from participants were categorized into themes. Braun and Clarke (2006, p. 10) argue that "theme captures something important about data concerning the research question, and presents some level of patterned response or meaning with the data set." The two themes of data were "The challenges faced by rural university lecturers and Solutions to mitigate challenges affecting lecturers in rural areas."

\subsection{Trustworthiness of Data}

Trustworthiness of data was enhanced by a pilot study, which eliminated ambiguities in the data generation instrument. Additionally, the researcher used member checking of the data from the participants in the focus group during discussions as a way to strengthen the trustworthiness of data.

\section{Data Analysis}

The data was analyzed using thematic analysis; data that were put in themes, examined and then interpreted. Responses of focus group discussions were grouped and recorded as suggested by Creswell and Poth (2018). The literature and theoretical framework tenets were factored in the data analysis.

\section{Ethical Considerations}

I was given gatekeepers permission and ethical clearance to conduct the study by the Ministry of Primary and Secondary Education in Zimbabwe. First, 1 explained the purpose of the study to the participants and they asked the questions to get clarity (Dube, 2020). After understanding that this study was purely an academic in addition that they their views, names and identities will be treated with confidentiality using pseudo names (Chidarikire, 2017). Second, participants then agreed to sign: the learners signed assent and consent forms and adults signed informed consent forms to allow children to participate in this study and they also signed informed consent forms to participate (Cohen, et al, 2018). Lastly, 1 informed the participants that they are allowed to withdrew from the study at any point without any questions being asked.

\section{Findings}

This section dealt with the findings on challenges faced by lecturers working in universities located in rural areas in Zimbabwe. Furthermore, the article explored the findings on solutions that can be implemented by universities, the Government, and other stakeholders to solve challenges faced by lecturers in rural areas. This is done with the thrust to fulfill the agenda of the Government 5.0 Higher and Tertiary Education agenda. The following section 
deals with theme 1: challenges faced by lecturers working in universities located in rural areas:

\section{The following segment deals with lack of house accommodation and office space}

On accommodation, Mrs Ncube commented that,

"I stay in one small room with my two grade 3 and grade four boys. The university does not offer accommodation to lecturers' without $\mathrm{PhDs}$ qualifications. This one room is very small and we share toilet with other eight tenants. I pay \$55us rent including water and electricity charges. This is very expensive considering my low salary"

In addition, Dr. Gono said,

"Yes, there is university policy that gives us as $\mathrm{PhD}$ holders free accommodation preference. However, many lecturers with $\mathrm{PhDs}$ at this university do not have decent university accommodation. I have been on university accommodation waiting list for the past two years."

On the lack of availability of office space, Mr Langton observed that,

"There are few and small lecturers offices at this university. We are 5 lecturers in one and this pose health risk during this Covid-19 era as we have already started to report for work. Some lecturers are now enemies due to fighting for office space”.

Furthermore, Dr. Memory explained that,

'Lecturers' offices have small chairs and wood desks that are used by lecturers. These small chairs and wood desks are very uncomfortable and some lecturers have developed backache problems".

From the above views, 1 found that lecturers working in universities located in rural areas are experiencing accommodation challenges. In Zimbabwe there is high shortage of university owned accommodation, which is free and affordable by lecturers. Consequently, some lecturers are living in cheap and overcrowded rooms and share toilets this exposes them to diseases such as Covid-19, cholera among others. This is contrary to the university is failing to fulfill its policy agreement that, all lecturers with $\mathrm{PhDs}$ are entitled to decent university accommodation. One the other hand, 1 found that, some universities located in rural areas have small offices spaces for lecturers with poor and low quality wood and steel chairs and desks

The next challenge dealt with by the participants is of lack of urgency in promotion and tenuring of probation lecturers:

On promotion Ms Moyo noted that,

"I applied to be promoted as senior lecturer two years ago but upto now 1 have not received an correspondence. I have met all university expectations to be promoted such as research publications. I have made several follow ups concerning promotion but to no avail. However, my colleagues from other universities have already been promoted this is 
frustrating".

In addition, Dr. Kundai is of the view that,

"The Human Resource Department and other departments that are responsible for promoting lack sense of urgency. This has de-motivated many lecturers. One experienced and hard working lecturer left this university because she was not promoted".

On being not tenured as full time lecture, Mr Mafa commented that,

"I am anxiety and highly stressed because 1 am not yet tenured as full time lecturer. This has brought lot of uncertainties and makes me to lose concentration at work. I am now spending lot of time applying for other jobs at other universities and companies".

From the above participants' views, 1 found that, some universities located in rural areas take long time to promote and tenured their qualified lecturers who possess all the required documents. In addition, 1 noted that other rural university's Human Resources officers and other personnel responsible for facilitating promotion are not taking proactive role in promoting and tenuring lecturers. Resultantly, failure to promote and tenuring lecturers early makes them to be stressed and increases anxiety

\section{The following paragraph unpacks the challenge of lack of computers, internet connectivity and data}

On lack of computers, Dr Charity expounded that,

"There is no laboratory with computer at our university. Some students and some lecturers do not own laptops and desktops and this makes them fail to teach and learn. Students and teachers using computers to do university work such as research and writing assignments".

In addition, Mrs Magomo argued,

"This university is failing to give us laptops but they expect us to use teaching and learning platforms such as Moodle. Universities in South Africa are giving laptops to lecturers and students. During this Covid-19 era we cannot have face-to-face teaching and learning processes".

On lack of internet connectivity, Dr Prince observed that,

"At our university campus in rural area there is good internet connectivity however, at our residential areas at growth point and other surrounding areas there is no free university internet. In addition, internet connectivity from Econet, Tel-One and other internet providers is very weak. This makes teaching and learning difficulty, lecturers and students are forced to go to university campus even on Sundays. This is dangerous during this Covid-19 period."

In support of internet connectivity challenge, Ms Moyo explained that,

"Sometimes we risk by going to the top of the mountain to search for internet 
connections. At the nearby mountain top, there is internet connectivity however, few days ago one female student was gang raped and robbed of her cell-phone and laptop while using internet in the mountain".

On the high cost of data, Dr Kundai explained that,

"This university does not give us free internet data to use at home. However, universities in South Africa and other countries are giving lecturers free data. The university does not give us data but expect us to respond to students' emails and to upload teaching and learning materials. We end - up using our personal money to purchase data and this is painful considering low salaries we are earning".

Mrs Ncube argued that,

"Internet data is very expensive in Zimbabwe. Most of us lecturers we cannot afford it with low salaries we are earning. We cannot use our personal money to purchase data to use for university work".

I found that some lecturers working in universities located in rural areas in Zimbabwe do not have computers to use at work because they cannot afford to buy them. On the other hand, 1 observed that there are internet connectivity problems in the residential areas where lecturers and students stay as a result some end up going to mountains to seek internet connectivity. Furthermore, 1 found that, data in Zimbabwe is very expensive and most lecturers cannot afford to buy data with their low salaries to use for work related purposes.

\section{The next section focuses on lack of transport and poor road networks}

Dr Charity opined that,

"In rural areas there are transport problems that affect lecturers and students. Transport problems are caused by poor road networks and few buses owned by university. Some lecturers and students end up walking and arrive at university tired and late."

Mrs Mafa stated that,

"Our university is located $17 \mathrm{kms}$ away from main road and this poses transport challenges. One lecturer was beaten and robbed of his laptop whilst walking from university".

Mr Langton noted that,

"Majority of lecturers at our university cannot afford to buy personal cars because of low salaries and those who have cars have no money to service their cars and fuelling them. As a result, they end up walking".

After analyzing the participants' view, 1 found that some lecturers are experiencing transport problems due to few universities buses and cars and also bad state of roads, as explained by the participants. The majority of rural areas in Zimbabwe have neglected road networks full of potholes, dilapidated bridges and uneven roads as a result transport operators shun these roads. Resultantly, some rural university lecturers' cars broke down frequently due to bad 
roads and they are failing to buy parts to replace the worn out parts because of lack of money. On the other hand, some lecturers' cars are working but they do not have money to buy fuel. In this era, car is a need and vital to the lecturers to arrive at work in time and not tired.

\section{The following segment deals with low salaries and no rural incentives}

On low salaries, Dr Prince had the following sentiments,

"Low university salaries in not only affecting rural university lecturers but all lecturers in Zimbabwe. I have observed that Zimbabwean universities lecturers are lowly paid as compared to their compatriots in other countries like South Africa, Botswana and Swaziland".

Dr Memory was of the view that,

"Rural university lecturers should have rural incentive allowance that is design to motivate them to work in rural located universities. Teachers working in rural areas in Zimbabwe are given rural allowance."

Mrs Ncube commented that,

"Zimbabwe lecturers are living below poverty datum line and we as lecturers have been reduced to laughing stock. We are no longer proud of our work, this is frustrating. We have children to feed, send to school, pay bills and other financial obligations. The low salaries are affecting us."

In this article, 1 found that some Zimbabwe university lecturers both at universities located in rural and urban areas are earning low same salaries based on their grades. I noted that, most lecturers in the rural areas where this study is located are having financial difficulties as they are failing to buy basic needs such food, rent, cars and paying children fees. The Zimbabwe Government is paying university lecturers salaries that are below poverty datum line and salaries are not competing with other regional and international universities. For example, in South Africa a lecturer earns around R50 000 and a Zimbabwean lecturer in same grade with same qualifications earns R8 500.

\section{The next phase pays attention on lack of research funding}

On challenge of research funding Dr Gono explained that,

"There is no funding for the lecturers who want to publish academic articles per the expectations of the university. We are struggling to publish because we do not have money to pay journals."

In addition, Mrs Ncube opined that,

"I applied for money to pay an article that was published in one highly rated international peer reviewed journal. The journal needed R13 425 for article to be published. The university gave me only R70 (I was given Zimbabwean dollars which 1 changed to rands). I had to use my personal savings to pay for this journal". 
Dr Kundai commented that,

"Most lecturers are no longer publishing academic articles because of lack of funding. One lecturer last published in 2013. This has negatively affected the production of new knowledge. This negatively affects teaching and learning as no new material will be available".

From the above narrations, 1 found that, some lecturers are no longer contributing to academic discourse through writing academic articles because of lack of money to pay journals that publish articles. Zimbabwe Universities are expected to research as stated in 5.0 Ministry of High Tertiary Education thrust. Many universities in Zimbabwe do not have funding allocated to research work consequently lecturers are de-motivated to write and publish in accredited high impact journals where the author is expected to pay publication fees. Some universities located in rural areas have little funding to support lecturers who want to publish but the money is very inadequate. This article does not only give challenges affecting lecturers working in universities located in rural areas but also offer solutions to mitigate these challenges.

\section{Theme 2: Solutions to mitigate the challenges faced by university lecturers in rural} areas

\section{The next section addresses provision of enough accommodation and office spaces}

On accommodation, Mrs Ncube commented that,

"The university should build spacious and enough staff accommodation to solve the issues of lack of staff accommodation."

Dr Gono further suggested that,

"Universities should partner with banks and other private land developers in building and provision of staff accommodation. The University will then mobilize finances to pay staff houses".

Dr Memory argued that,

"Government through Ministry of Higher and Tertiary Education in Zimbabwe should provide zero interest house loans to university lecturers that help them to buy or build houses. Currently, Government has a house loan program for all civil service workers but interests rates are too exorbitant and many lecturers cannot afford to pay the money back".

Mr Langton is of the view that,

"Housing allowance offered by university should at least pay for three rooms rent in decent low density locations. Currently, housing allowance cannot pay for a single room rent in high density suburbs".

One of the solutions 1 found in this article, is that the universities located in rural areas as responsible authorities should build enough housing units to accommodate lectures. In 
addition, noted that, the universities should partners with banks and other private organizations that offer cheap housing loans that are affordable by lecturers. I argued that, it is a dream of every lecturer to own a house and leave it as an inheritance to his / her children and other relatives.

\section{The following segment addresses increased urgency in promotion and tenuring of probation lecturers}

On promotion Ms Moyo noted that,

"The people who are responsible for promotions of lecturers should urgently do their work and facilitate the promotion of lecturers. Anyone with qualifications and met the promotion criteria should be promoted quickly and this motivates lecturers in universities located in rural areas".

On tenuring Dr Charity argued that,

"A month before the end of probation period, 1 suggest that, if the lecturer has satisfactory met the expectations of the university he or she should be tenured without delay. For delaying in tenuring the lecturers on probation frustrates and makes them to loss concentration at work".

The other solution 1 found in this paper, is that there is need for urgent action by rural universities' Human Resources Office personnel and other responsible officers to promote and tenure qualified and deserving lecturers quickly. I argue that, promotion and tuenuring of lecturers in universities located in rural areas act as motivation to the academic staff. I also found that, some lecturers in universities located in rural areas have resigned after failing to be promoted and ternured. Promotion and being ternued show that the university recognizes the lecturers' hard-work, commitment and contribution to academic body knowledge through research and teaching.

\section{This paragraph focuses on computers, internet connectivity and data availability}

On the availability of computers Mrs Magono suggested that,

"The university should buy and give each lecturer a computer as in South Africa. I have noted that, in South Africa, most universities give their lecturers laptops and desktops"

Dr Prince opined that,

"The university should partner with computer providers, offer cheap and great laptops to the lecturers. The lecturers will then pay low monthly premiums whilst using computers."

On internet connectivity, Ms Moyo said,

"The university should engage the internet service providers and the Government to provide internet infrastructure in our residential areas this helps us to easily get internet connectivity." 
In addition, Dr Kundai suggested that,

"Police officers should be deployed in the mountain where we are getting internet connective. This mountain has been invaded by thieves, robbers and murderous who take advantage of our internet desperation."

On data availability, Dr Charity is of the view that,

"The university should provide free data to all lecturers to enable them to get internet access at home. This helps lecturers to do their work at home in line with Covid-19 rules and allows them to work at night if they so wish."

In support for data availability, Mr Mafa, explained that,

"The university should partner with data providers and Government to provide cheap data / discount cost data. This helps the lecturers to buy enough data to do their work."

On how to solve computer challenges, I found that, the universities should give free computers to their lecturers. To enhance above argument, observed that South African Universities give their lecturers laptops and desktops to use. In addition, 1 found that, if the universities cannot provide free laptops to their lecturers they can engage private companies to offer low cost laptops on cash or credit terms. On the other hand, I noted that, internet connective problems can be solved through a collaborative work between the Government and internet providers to put internet infrastructure in marginalized rural areas where universities are located. To deal with high cost of data, 1 found that, some universities university are providing free data as the case with South African universities that are giving their lecturers free data to do online lessons and other teaching related issues.

\section{This segment unpacks transport and good road network issues}

On transport availability, Dr Gono noted that,

"The university should enough provide buses and cars that stick to the specific timetable and pickup points. Currently, some buses came early or late and this disadvantages lecturers and students".

In addition, Dr Memory suggested that,

"The University, Government and private sector should agree to provide car loans for lecturers at cheap premiums. It is a dream of every lecturer to own a car for both personal and work related use."

Mr Langton observed that,

"I recommend that, the roads be urgently repaired and the road should be tarred. The roads to our university campus are in bad state, they a big potholes and not tarred. Many cars have their tyres have been damaged and other car parts have been affected. Many transport operators are shunning our university roads due to their poor state."

On the issue of transport, I found that one of the solutions is that, the university should 
adequately provide buses and cars to transport its lecturers to and fro work. In addition, 1 am of the view that, transport challenges can be reduced through the agreement between Government, universities and car suppliers to provide cheap car loan facilities to lecturers working in the universities located in the rural areas. On the other hand, poor road network has negatively affected the availability of reliable to and fro university site, therefore the university authorities should continuously engage Ministry of Transport to continuously maintain dust roads. More so, universities located in rural areas should engage Zimbabwe Government and private sector to allocate funds to put tare roads to university from the main roads.

\section{This section deals with competitive salaries and good rural incentives}

Ms Moyo commented that,

"Zimbabwe Government should pay lecturers salaries that are highly competitive to other lecturers in Zimbabwe. Currently junior lecturers in South Africa earn R50 000 but in Zimbabwe lecturers earn R8 500 (after converting Zimbabwe dollar to Rands). This difference is too big and causes lecturers in Zimbabwe to migrate to South Africa to look for greener pastures."

Dr Prince is of the view that,

"There is need to pay lecturers using foreign money such as US\$ or Rands. The reason is that, some goods and services are being priced in US\$ and Rand in Zimbabwe. These currencies do not get easily affected by inflation as compared to Zimbabwean dollars. Prices and goods perked in Zimbabwean dollars are currently increasing during month end".

On rural allowances, Dr Kundai advocated that,

"I propose that, university lecturers working in universities located in rural areas should be given rural allowances. I have observed that, teachers teaching primary and secondary schools in rural areas in Zimbabwe are given rural allowances. Rural allowances act as motivation to lecturers and teachers in rural learning spaces."

On improving lecturers' salaries and rural allowances, one of the solutions 1 found is that, Government should peg lecturers' salaries with the lecturers in the neighboring country South Africa. In South Africa, lecturers are paid slightly less than R50 000 whereas a lecturer in Zimbabwe with same qualifications get about R8 500. The Government of Zimbabwe may pay lecturers in Zimbabwean dollars which is equivalent to amount being paid to South African counterparts. Alternatively, the Zimbabwe Government should pay lecturers using foreign currency such as US\$ dollars. The reason of paying in foreign currency salaries is that, some goods and services such as fuel, medication, house rents among others are being sold in foreign currency. My perspective is that, lecturers in universities located in rural areas should be given rural allowances, because they experience rural hardships such as lack of transport and if transport is available it is expensive.

\section{Lastly, this section deals with research funding}


Mrs Ncube proposed that,

"The University should set aside funds to support research studies that create knowledge and solutions to challenges faced by communities."

Dr Charity is of the view that,

"In South Africa, the Department of Higher Education and Training supports universities' research studies through grants. South Africa universities that publish academic articles are financially rewarded. This motivates lecturers to engage in ground breaking research work. Therefore, Ministry of High and Tertiary Education in Zimbabwe should adequately financial support researchers through funding their research work."

Mr Mafa argued that,

"Non-Governmental Organizations such as UNICEF should be engaged to support university researchers. Non-Governmental Organizations play a great role in teaching and learning processes in Zimbabwe and beyond."

Dr Gono commented that,

"There should be a refund of the money paid by scholars who publish using universities credentials, which is after they have successfully published and paid for their papers in accredited journals."

To enhance research funding issues, 1 found that, universities should allocate enough financial support to lecturers to engage in writing academic articles to fulfill Education 5.0 thrust of the Government. The Government of Zimbabwe should also give universities grants that are specific for research studies, 1 noted that South Africa universities, lecturers through publishing grants channeled through Department of Higher Education. Furthermore, the Government, universities should engage Non-Governmental Organizations interested in education and training such as UNICEF to support with money, computers and other research equipment needed by research in rural based universities.

\section{Discussion}

This section dealt with the discussion on challenges faced by lecturers working in universities located in rural areas in Zimbabwe. Furthermore, the article explored the discussion on solutions that can be implemented by universities within rural communities, the Government, and other stakeholders to solve challenges faced by lecturers in rural areas. This is done with the thrust to fulfill the agenda of the Government 5.0 Higher and Tertiary Education agenda.

The following section dealt with Theme 1: challenges faced by lecturers working in universities located in rural areas:

\section{The following segment deals with lack of house accommodation and office space}

I observed that, there is lack of lecturers' accommodation in many rural universities in Zimbabwe. There literature evidence that show that, there is accommodation problems of lecturers and other educators in rural areas (Herald, 2021; Progressive Teachers' Union 
Report, 2020). The lack of accommodation creates health hazards among lecturers who stay in overcrowded and unhealthy houses. Furthermore, universities in rural areas have inadequate offices for lecturers to work, low quality wood and steel chairs and desks (Hlalele, 2019). Small wood and steel chairs used by university lecturers in their offices may cause diseases such as back aches. Sick lecturers will not be able to teach properly and this affect teaching and learning process (Chinyoka \& Naindu, 2014). According to Maslow's hierarchy of needs accommodation and office spaces are some of the basic physiological needs that should be addressed before a person moves to the next level (Mwamwenda, 2014). I agree with the assertion that, accommodation and office spaces crises affect lecturers in execution of their duties as postulated by Maslow's theory of motivation (Snowman et al., 2009).

The next challenge dealt with by the participants is of lack of urgency in promotion and tenuring of probation lecturers:

I noted that, some universities located in rural areas take long time to promote and tenured their qualified lecturers who possess all the required documents. Failure to promote and tenure lecturers at rural universities makes them uncertain, fearful and no job security (Petry, 2011). In addition, other rural universities' Human Resources officers and other personnel responsible for facilitating promotion are not taking proactive role in promoting and tenuring lecturers. According to Maslow's safety needs level, lecturers need job security and want to free safe at work knowing that their work is secure (Chingombe, 2019; Haung, Daizen, \& Kim, 2017; Mwamwenda, 2014).

\section{The following paragraph unpacks the challenge of lack of computers, internet connectivity and data}

Some universities located in rural areas in Zimbabwe do not have computers to use at work because they cannot afford to buy them. Some scholars support the view that, some rural schools do not have computers to use (Dube, 2020; Tarisayi \& Manhibi, 2018). In Zimbabwe, there is internet connectivity problems in the residential areas where lecturers stay as a result some end up going to mountains to seek internet connectivity (Dube, 2020; Herald, 2021). On the other hand, Zimbabwe has very expensive and most lecturers cannot afford to buy data with their low salaries to use for work related purposes (Newsday, 2020; Progressive Teachers Union, 2020). The lack of computers, unavailability of data and connectivity problems negatively affect teaching and learning process as Zimbabwe join other nations in using Moodle and other online platforms (Gumbo, 2019; Mpungose, 2020). I argue that, computers, data and internet connectivity have become basic needs in this era of technology as a result, this resonates with Maslow's hierarchy of needs level one. Lecturers should own laptops, have data and internet connective access to enhance their teaching and learning.

\section{The next section focuses on lack of transport and poor road networks}

In Zimbabwe rural areas some lecturers are experiencing transport problems due to few universities buses and cars and also bad state of roads, as explained by the participants. Rural areas in Zimbabwe have neglected road networks full of potholes, dilapidated bridges and uneven roads as a result transport operators shun these roads (Chidarikire, Hlalele, \&Tarisayi, 
2021; Newsday, 2020). Some lecturers' cars are working but they do not have money to buy fuel. In this era, car is a need and vital to the lecturers to arrive at work in time and not tired. Consequently, 1 subscribe to the notion that, cars and other transport models are basic needs as postulated by Maslow's hierarchy of needs first level (Santrock, 2009).

\section{The following segment deals with low salaries and no rural incentives}

Majority of Zimbabwe university lecturers both at universities located in rural and urban areas are earning low same salaries based on their grades. I noted, most lecturers in the rural areas do not have enough money to buy basic commodities and services for example food and paying children's schools fees (Zimbabwe Congress Trade Union, 2021). Currently, Zimbabwe Government is paying university lecturers salaries that are below poverty datum line and salaries are not competing with other regional and international universities. Poor salaries and lack of rural allowances negatively impact on the psychological and well-being of the Zimbabwean lecturers as a result they will not execute their teaching and learning mandate (Koen, 2003; Petry, 2011; O’Hara, 2015).

\section{The next phase pays attention on lack of research funding}

Some lecturers are no longer contributing to academic discourse through writing academic articles because of lack of money to pay journals that publish articles. Zimbabwe Universities are expected to research as stated in 5.0 Ministry of High Tertiary Education thrust. Universities located in rural areas in Zimbabwe do not have funding allocated to research work consequently lecturers are de-motivated to publish (Kariwo, 2007; Majoni, 2014; Nherera, 2000). Some universities located in rural areas have little funding to support lecturers who want to publish but the money is very inadequate. Money is a basic need that is critical to lecturers' publishing work as observed in Maslow's hierarchy of needs (Chingombe, 2019). Lack of money incapacitates lectures' drive to publish academic articles.

This article does not only give challenges affecting lecturers working in universities located in rural areas but also offer solutions to mitigate these challenges.

Theme 2: Solutions to mitigate the challenges faced by university lecturers in rural areas

\section{The next section addresses provision of enough accommodation and office spaces}

One of the solutions on the accommodation is that the universities located in rural areas have as responsible authority should build enough housing units to accommodate lectures. In addition, participants suggest that, the universities should partners with banks and other private organizations that offer cheap housing loans that are affordable by lecturers (Public Service Commission of Zimbabwe, 2021).I argue that, is the dream of every lecturer to own a house and leave it as an inheritance to his / her children and other relatives. Participants are of the view that, housing allowances should be increased to the level where one can rent at least three decent rooms and be able to pay service charges without any struggle. Renting a decent and affordable and own a house act as motivational factor to lecturers and they will do their jobs with peace of mind (Mwamwenda, 2014). 
The following segment addresses increased urgency in promotion and tenuring of probation lecturers

In this paper, 1 noted that there is need for urgent action by Human Resources Office personnel and other responsible officers to promote and tenure qualified and deserving lecturers. I argued that promotion and tuenuring of lecturers in universities located in rural areas act as motivation to the promoted staff and to those who want to be promoted (Mwamwenda, 2014). Recognition through promotion and tenuring are key tenants of Maslow's third level of hierarchy of needs therefore all human being strive for recognition and belonging (Kufakunesu, 2019).

\section{This paragraph focuses on computers, internet connectivity and data availability}

The universities should give free computers to their lecturers. Recently one university in Zimbabwe located in urban area engaged a local company that is providing laptops to lecturers at a very high cost; consequently, most lecturers have refused to take them (Newsday, 2008). On the other hand, internet connective problems can be solved through a collaborative work between the Government and internet providers to put internet infrastructure in marginalized rural areas where universities are located (Ministry of Information and Publicity, 2020). The participants urged the university leadership to vigorously engage the Government and internet providers to fast track the provision of internet as a way to promote e-learning during this Covid-19 era and beyond. In addition, 1 am of the view that, internet providers and university can make a special arrangement to offer cheap / reduced priced data bundle for lecturers (Chidarikire, Hlalele, \& Tarisayi, 2021).

\section{This segment unpacks transport and good road network issues}

On the issue of transport, the university should adequately provide buses and cars to transport its lecturers to and fro work. The transport challenges faced by university lecturers in Zimbabwe rural areas can be reduced through the agreement between Government, universities and car suppliers to provide cheap car loan facilities to lecturers working in the universities located in the rural areas. Poor road network has negatively affected the availability of reliable to and fro university site, therefore the university authorities should continuously engage Ministry of Transport to continuously maintain dust road and to engage Government to allocate funds to put tare road to university from the main road.

\section{This section deals with competitive salaries and good rural incentives}

On improving lecturers' salaries and rural allowances, Government of Zimbabwe should pay her workers competitive salaries. Paying university lecturers regional and competitive salaries to Zimbabwe universities lecturers is supported in Sunday Mail (2021), where Government promised to pay salaries. These salaries may be in foreign currency or local currency that is equivalent. The reason of paying in foreign currency salaries is that, some goods and services such as fuel, medication, house rents among others are being sold in foreign currency (Newsday, 2008). Lecturers in universities located in rural areas should be given rural allowances, because they experience rural hardships such as lack of transport and if transport is available it is expensive. 


\section{Lastly, this section dealt with research funding}

To enhance research funding issues, universities should allocate enough financial support to lecturers to engage in writing academic articles to fulfill Education 5.0 thrust of the Government (Chidarikire \& Hlalele, 2021). The Government should also give universities grants that are specific for research studies, to validate this argument, the participants gave an example of South Africa, which support her researchers through grants channeled through Department of Higher Education (Udefi, 2014). Furthermore, the Government, universities should engage Non-Governmental Organizations interested in education and training such as UNICEF to support with money, computers and other research equipment needed by research in rural based universities.

\section{Conclusion}

There are limited / no literature that specifically address challenges and solutions affecting lecturers in Zimbabwe universities located in rural areas. Most of the articles focusing on challenges in Zimbabwe universities look at universities in urban areas and other articles look at challenges facing one specific university without considering its location. Hence, there was need to specifically look at challenges faced by lecturers at universities located in rural areas. This article unpacked the challenges faced by the lecturers working in the universities located in rural areas in Zimbabwe. Some of the challenges noted in this discursive article include lack of accommodation, transport, poor salaries, poor internet connectivity, lack of computers among other challenges. The article also offered probably solutions to mitigate challenges faced by universities lecturers working in rural areas such as universities should build and allocate free spacious accommodation to lecturers. In addition, the universities should give lecturers free computers and money to pay for article publications in recognized and accredited journals. This article was couched in Maslow's hierarchy of needs using its five levels namely physiological, safety, love and belonging, self-esteem and self-actualization. I found this theory suitable for this paper as it resonates well with issues under discussion. This article was qualitative and case study was used. Data were generated through focus group discussions and data was analyzed through thematic content analysis.

\section{Recommendations}

This article recommended that the Government, universities and other stakeholders should work collectively to address the challenges faced by lecturers in universities in rural areas. Universities are critical in producing labor force, machinery, knowledge and skills that are vital in the economic, social, political and moral development of Zimbabwe and beyond. The article also recommended that, further studies should be undertaken using quantitative or mixed methods in addressing this phenomenon and other areas this article may have missed. Lastly, 1 urge the Government and universities to actively engage lecturers when coming up with the solution to mitigate their challenges. Some solutions by the Government and universities have failed to have buy-in from the lecturers because they were 'imposed' from the top. 


\section{Acknowledgement and sponsorship}

I acknowledge the views offered by participants in this article. The researcher received no funding from any funding agency in the public, commercial or non-profit sectors.

\section{References}

Braun, V., \& Clarke, V. (2006). Using thematic analysis in psychology. Qualitative Research in Psychology Journal, 2(3), 77-101. https://doi.org/10.1191/1478088706qp063oa

Chidarikire, M. (2017). Peer counselling strategy for alleviating drug abuse in Zimbabwe rural learning ecologies. Unpublished doctoral thesis. Bloemfontein: University of Free State.

Chidarikire, M., Hlalele, D. J., \& Tarisayi, K. S. (2021). Exploring safety in disaster-induced displacements in Tokwe-Mukosi, Zimbabwe. Jamba Journal of Disaster Risky Studies, 13(1), $1-9$.

Chingombe. (2019). Reflecting on the use of corporal punishment in Zimbabwean schools: An ecological systems approach. Educational Research International, 6(2), 96-102.

Chinyoka, K., \& Ganga, E. (2014). An exploration of psychological effects of poverty on child development in Ngundu in Zimbabwe. NAWA Journal of Language Communication, $4(2), 143-154$.

Chinyoka, K., \& Naidu, N. (2014). Underage and unprotected: Psychosocial effects of child labor on the academic performance of learners in Zimbabwe. Journal of Psychology, 5(1), 65-74. https://doi.org/10.1080/09764224.2014.11885506

Cohen, L., Manion, L., \& Morrison, K. (2018). Research Methods in Education (8th ed.). Routledge Publishers: Boston. https://doi.org/10.4324/9781315456539

Creswell, J. W. (2010). Research Design: Qualitative, Quantitative and Mixed Methods Approaches (3rd ed.). London: Sage Publication

Creswell, J. W., \& Poth, C. N. (2018). Qualitative Inquiry and Research Design (4th ed). Sage Publisher: London.

Dube, B. (2020). Rural online learning in the context of Covid-19 in South Africa: Evoking an inclusive approach. Multidisciplinary Journal of Educational Research, 10(2), 135-157. https://doi.org/10.17583/remie.2020.5607

Gumbo, M. (2019). Online or Offline supervision? Postgraduate supervisors state their position at University of South Africa. South African Journal of Higher Education, 3(3), 1-25. https://doi.org/10.20853/33-1-2673

Haung, F., Daizen, T., \& Kin, Y. (2017). University lecturers perceptions on their income. Kagamiyana, 1(2), 2-6.

Herald. (2021). Tackling Covid-19 lockdown teen pregnancies and school dropouts. Retrieved March 15, 2021, from http://www.herald.co.zw 


\section{Macrothink}

International Journal of Social Science Research

ISSN 2327-5510

2021, Vol. 9, No. 2

Hlalele, D. (2019). Understanding Teacher Transnational Migration. Retrieved April 7, 2021, from https://journals.sagepub.com

Kariwo, T., M. (2007). Widening Access in Higher Education in Zimbabwe. University of Alberta, 1(2), 7-14. https://doi.org/10.1057/palgrave.hep.8300142

Koen, C. (2003). Academics. Human Resources Development Review, 1(3), 501-517.

Kufakunesu, J. G. (2017). Personality Development. Masvingo: Great Zimbabwe.

Majoni, C. (2014). Challenges facing universities education in Zimbabwe. Greener Journal of Education Training Studies, 2(1), 20-24. https://doi.org/10.15580/GJETS.2014.1.021714111

Ministry of Information and Publicity in Zimbabwe. (2020). Workers' Welfare. Retrieved May 2, 2021, from http://www.mininfopub.gov.zw

Mpungose, C. B. (2020). Beyond limits: Lecturers reflections on moodle uptake in South African universities. Education and Information Technologies, 2(5), 5033-5052. https://doi.org/10.1007/s10639-020-10190-8

Mwamwenda, T. S. (2014). Educational Psychology: An African Perspective. Sandton: Heinemann.

Newsday, Z. (2020). Covid-19 ticking time bomb in Zimbabwe. Retrieved April 10, 2021, from https://www.newsday.co.zw

Nherera, C. (2000). The role of emerging universities in Zimbabwe. Journal of Educational Research, 12(3), 1-10.

O'Hara, M. (2015). Universities lecturers on the breadline: Is the UK following in the American footsteps? Retrieved April 2, 2021, from http://www.theguardian.com

Petry, G. (2011). Top ten workplace issues for Faculty members and Higher Education Professionals. Retrieved April 11, 2021, from http://www.aaup.org/article/top-ten-workplacesissues

Public Service Commission of Zimbabwe. (2021). Civil servants loan facility set for role out. Retrieved May 2, 2021, from https://www.herald.co.zw

Progressive Teachers Union of Zimbabwe. (2020). Zimbabwe: Government must pay teachers decent salaries. Retrieved May 2, 2020, from https://www.ei-ie.org

Snowman, J., McCown, R., \& Bieher, R. (2014). Psychology applied to teaching (12th ed.). New York: Hughton Mifflin Company

Sowetan Newspaper. (2020). South Africa record daily Covid-19 cases of nearly 18, 000. Retrieved May 7, 2021, from https://www.sowetanlive.co.za

Sunday Mail, Zimbabwe. (2021). Pay rise for public, private sector imminent. Retrieved May 7, 2021, from https://www.sundaymail.co.zw 


\section{Macrothink}

International Journal of Social Science Research

ISSN 2327-5510 2021, Vol. 9, No. 2

Tarisayi, K., \& Manhibi, R. (2017). Social media tools in Education: A case of WhatsApp use by Heritage Studies Teachers in Zimbabwe. https://doi.org/10.15580/GJSS.2017.4.082217108

Thao, N. V., \& Herman. (2020). An Analysis of Deixis to Song Lyrics "My Heart Will Go on" by Celine Dion. Communication and Linguistics Studies, 6(2), 23-26. https://doi.org/10.11648/j.cls.20200602.12

Udefi, A. (2014). The trouble with Nigerian Universities: Bogus Policy and speculative ideology. Global Journal of Social Sciences, 1(3), 1-17. https://doi.org/10.4314/gjss.v13i1.1

\section{Copyrights}

Copyright for this article is retained by the author(s), with first publication rights granted to the journal.

This is an open-access article distributed under the terms and conditions of the Creative Commons Attribution license (http://creativecommons.org/licenses/by/4.0/). 